\title{
Dental Drug Information Websites Resources: New Initiative Project in Saudi Arabia
}

\author{
Yousef Ahmed Alomi* iD BSC. \\ Pharm, MSc. Clin Pharm, BCPS, BCNSP, \\ DiBA, CDE \\ Critical Care Clinical Pharmacists TPN \\ Clinical Pharmacist, Freelancer Business \\ Planner, Content Editor, and Data Analyst, \\ Riyadh, SAUDI ARABIA. \\ Hanin Sumaydan Saleam Aljohani \\ Ministry of Health, Riyadh, SAUDI ARABIA. \\ Arub Abdullah Batil Albatil \\ Majmaah University, College of Dentistry \\ Faculty of Dentistry at Al Zulfi Riyadh, \\ SAUDI ARABIA.
}

\section{Correspondence:}

Dr. Yousef Ahmed Alomi, BSc. Pharm,

MSc. Clin Pharm, BCPS, BCNSP, DiBA, CDE

Critical Care Clinical Pharmacists

TPN Clinical Pharmacist, Freelancer

Business Planner, Content Editor, and

Data Analyst, P.O.BOX 100, Riyadh

11392, Riyadh, SAUDI ARABIA.

Phone no: +966504417712

E-mail:yalomi@gmail.com
Received: 21-10-2020

Approved: 25-01-2021

Copyright: (c) the author(s),publisher and licensee Pharmacology, Toxicology and Biomedical Reports. This is an open-access article distributed under the terms of the Creative Commons Attribution NonCommercial License, which permits unrestricted non-commercial use, distribution, and reproduction in any medium, provided the original work is properly cited.

This is an open access article distributed under the terms of the Creative Commons Attribution-NonCommercial-ShareAlike 4.0 License

Access this article online

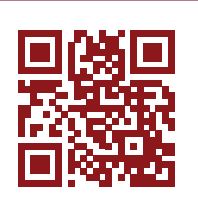

www.ptbreports.org

DOI:

10.5530/PTB.2021.7.10

\begin{abstract}
Objectives: All healthcare professionals necessity to improve and update their medical and pharmaceutical knowledge, including dentists. There are numerous types of dental medications, including drug information website resources. The current review is to reconnoiter references websites of medications in the dental care. Methods: It is a literature review of a drug information website for dentists. Probing was done in PubMed and Medline about this field. The search encompassed all study designs but was not limited to the observation study, clinical trial, meta-analysis and systemic, and review articles. The current topic debated the market assessment demand, team and cost management of the project, quality and risk management of the project. It was rationalized on selected dental drug websites designed with medications coverage, frequency updated, and responsible publisher. Results: More than 13 drug information websites for dental practice had been intended. The websites consisted of free governmental or healthcare organizations websites highlighting international medications regulation or local drug regulatory affairs with mobile applications format. Free non-governmental drug information website entailed of drug therapy as part of disease management and other medication patient education websites. All websites of dental drug information resources should be measured undergraduate and postgraduate dental practitioners. Conclusion: Dental drug information resources website is real-world and more accessible than other resources. Therefore, implementation of the current project is highly recommended for dental colleges and healthcare organizations.

Key words: Dental, Drug, Information, Websites, Resources, Saudi Arabia.
\end{abstract}

\section{INTRODUCTION}

The term "drug information center" denoted to a facility dedicated to and specialized in distributing drug information and related issues. The goal of the drug information center is to deliver authentically individualized, reliable, appropriate, and impartial drug information to consumers and healthcare professionals around the country for health care and drug safety concerns by answering to their calls on all critical issues relating to drug information, uses, and side effects. ${ }^{1}$ The term "drug information center" mentioned to a facility dedicated to and specialized in distributing drug information and related issues. The goal of the drug information center is to offer authentically individualized, reliable, appropriate, and impartial drug information to consumers and healthcare professionals around the country for health care and drug safety concerns by responding to their calls on all critical issues relating to drug information, uses, and side effects. ${ }^{1}$ Drug information resources were part of the drug information services of pharmacy practice. ${ }^{2}$ They are numerous types of drug information resources to meet the healthcare provider's requirements. Some demand to find simple drug information about trade name or dosage form and others need more deep knowledge and comprehensive information about drug therapy. ${ }^{3}$ The dentists among healthcare professionals demand drug information references. There are tertiary resources, which are very easy to read with short and summary information. Those tertiary resources might be as regular paper books, and newly as a website. Some publishers currently composed all their tertiary textbooks and organized them at website collection with low prices and more accessible, reachable, and searchable for each information. ${ }^{4}$ Other websites are accomplished by governmental or private, or professional scientific or medical societies. ${ }^{5}$ Various investigations deliberated the dentist's knowledge or website drug information resources. 5 The answer among preceding studies was not fortified. As a result, the review of literature about website drug information references is wanted. Based on the best of the author's knowledge, there is no textbook or literature review the dental website drug information resources. The aim of the current review is to assert a collection of the drug information website in the dental practice.

\section{METHODS}

It is a literature review of drug information references website for dentist or drug information resources websites employed during dental care. The PubMed search includes drug information resources website and the dentist or drug information resources website and dentistry or drug information references website. The word is used as a general term, not a subject term. The search comprised all types of studies Clinical Study, Clinical Trial, Clinical Trial, Phase I, Clinical Trial, Phase II, Clinical Trial, Phase III, Clinical 
Trial, Phase IV, Controlled Clinical Trial, Meta-Analysis, Observational Study, Practice Guideline, Randomized Controlled Trial, Review and Systematic Review. The searching date from 1985 to May 2021. The Pubmed search words counting as follows:

\section{Dentistry Drug Information Website Filters: Full text, Humans, English}

((“dentistry"[MeSH Terms] OR "dentistry”[All Fields] OR "dentistry $\mathrm{s}$ "[All Fields]) AND "drug"[All Fields] AND ("inform"[All Fields] OR "informal"[All Fields] OR "informality"[All Fields] OR "informally"[All Fields] OR "informant"[All Fields] OR "informant $s$ "[All Fields] OR "informants"[All Fields] OR "information"[All Fields] OR "information"[All Fields] OR "informational"[All Fields] OR "information"[All Fields] OR "informative"[All Fields] OR "informatively" [All Fields] OR "informativeness"[All Fields] OR “informativity”[All Fields] OR "informed”[All Fields] OR "informer" [All Fields] OR "informers"[All Fields] OR "informing"[All Fields] OR "informs"[All Fields]) AND ("website"[All Fields] OR "website s"[All Fields] OR "websites"[All Fields])) AND ((fft[Filter]) AND (humans[Filter]) AND (english[Filter]))

\section{Dentist Drug Information Website Filters: Full text,} Humans, English

((“dentist s"[All Fields] OR "dentists" [MeSH Terms] OR "dentists"[All Fields] OR "dentist"[All Fields]) AND "drug"[All Fields] AND ("inform"[All Fields] OR "informal"[All Fields] OR "informality"[All Fields] OR "informally"[All Fields] OR "informant"[All Fields] OR "informant s" $s$ All Fields $] \quad$ OR "informants"[All Fields $] \quad O R$ "information" [All Fields $]$ OR "information" [All Fields $]$ OR "informational"[All Fields] OR "information"[All Fields] OR "informative"[All Fields] OR "informatively" [All Fields $]$ OR "informativeness"[All Fields] OR "informativity"[All Fields] OR "informed"[All Fields] OR "informer"[All Fields] OR "informers"[All Fields] OR "informing"[All Fields] OR "informs"[All Fields]) AND ("website"[All Fields] OR "website s"[All Fields] OR "websites"[All Fields])) AND ((fft[Filter]) AND (humans[Filter]) AND (english[Filter]))

\section{Dental Drug Information Website Filters: Full text,} Humans, English

(("dental health services"[MeSH Terms] OR ("dental”[All Fields] AND "health"[All Fields] AND "services"[All Fields]) OR "dental health services"[All Fields] OR "dental"[All Fields] OR "dentally"[All Fields] OR "dentals"[All Fields]) AND "drug"[All Fields] AND ("inform"[All Fields] OR "informal"[All Fields] OR "informality"[All Fields] OR "informally"[All Fields] OR "informant"[All Fields] OR "informant $\mathrm{s}$ "[All Fields] OR “informants"[All Fields] OR “information"[All Fields] OR “information"[All Fields] OR "informational"[All Fields] OR "information"[All Fields] OR "informative"[All Fields] OR "informatively"[All Fields] OR "informativeness"[All Fields] OR “informativity"[All Fields] OR "informed"[All Fields] OR "informer" [All Fields] OR "informers"[All Fields] OR "informing"[All Fields] OR "informs"[All Fields]) AND ("website"[All Fields] OR "website s"[All Fields] OR "websites"[All Fields])) AND ((fft[Filter]) AND (humans[Filter]) AND (english[Filter]))

\section{Dental Drug Information Online Filters: Full text, Humans, English}

(("dental health services"[MeSH Terms] OR ("dental"[All Fields] AND "health"[All Fields] AND "services"[All Fields]) OR "dental health services"[All Fields] OR "dental"[All Fields] OR "dentally"[All Fields] OR "dentals"[All Fields]) AND "drug"[All Fields] AND ("inform"[All
Fields] OR "informal"[All Fields] OR "informality"[All Fields] OR "informally"[All Fields] OR "informant"[All Fields] OR "informant $s "$ [All Fields] OR "informants"[All Fields] OR "information"[All Fields] OR "information"[All Fields] OR "informational"[All Fields] OR “information"[All Fields] OR "informative"[All Fields] OR "informatively"[All Fields] OR "informativeness"[All Fields] OR "informativity" [All Fields] OR "informed"[All Fields] OR "informer" [All Fields] OR "informers"[All Fields] OR "informing"[All Fields] OR “informs"[All Fields]) AND "online"[All Fields]) AND ((fft[Filter]) AND (humans[Filter]) AND (english[Filter]))

\section{Dentist Drug Information Online Filters: Full text,}

Humans, English

(“"dentist s"[All Fields] OR "dentists"[MeSH Terms] OR "dentists"[All Fields] OR "dentist"[All Fields]) AND "drug"[All Fields] AND ("inform"[All Fields] OR "informal"[All Fields] OR "informality"[All Fields] OR "informally"[All Fields] OR "informant"[All Fields] OR "informants"[AllFields] OR "informants"[AllFields] OR "information"[All Fields] OR "information"[All Fields] OR "informational"[All Fields] OR "information"[All Fields] OR "informative"[All Fields] OR "informatively"[All Fields] OR "informativeness"[All Fields] OR "informativity"[All Fields] OR "informed"[All Fields] OR "informer" [All Fields] OR "informers"[All Fields] OR "informing"[All Fields] OR "informs"[All Fields]) AND "online"[All Fields]) AND ((fft[Filter]) AND (humans[Filter]) AND (english[Filter]))

\section{Dentistry Drug Information Online Filters: Full text,} Humans, English

(("dentistry"[MeSH Terms] OR "dentistry"[All Fields] OR "dentistry s"[All Fields]) AND "drug"[All Fields] AND ("inform"[All Fields] OR “informal"[All Fields] OR “informality"[All Fields] OR "informally"[All Fields] OR "informant"[All Fields] OR "informant $s$ "[All Fields] OR “informants"[All Fields] OR “information"[All Fields] OR "information"[All Fields] OR "informational"[All Fields] OR "information"[All Fields] OR "informative"[All Fields] OR "informatively" [All Fields] OR "informativeness"[All Fields] OR "informativity" [All Fields] OR "informed" [All Fields] OR "informer" [All Fields] OR "informers"[All Fields] OR “informing"[All Fields] OR "informs"[All Fields]) AND "online"[All Fields]) AND ((fft[Filter]) AND (humans[Filter]) AND (english[Filter]))

\section{Dentistry Drug Information Internet Filters: Full text, Humans, English}

((“dentistry"[MeSH Terms] OR "dentistry"[All Fields] OR "dentistry s"[All Fields]) AND "drug"[All Fields] AND ("inform"[All Fields] OR "informal"[All Fields] OR "informality" [All Fields] OR "informally"[All Fields] OR "informant"[All Fields] OR "informant s"[All Fields] OR "informants"[All Fields] OR "information"[All Fields] OR "information s"[All Fields] OR "informational"[All Fields] OR "information"[All Fields] OR "informative"[All Fields] OR "informatively"[All Fields] OR "informativeness"[All Fields] OR "informativity"[All Fields] OR "informed"[All Fields] OR "informer"[All Fields] OR "informers"[All Fields] OR "informing"[All Fields] OR "informs"[All Fields]) AND ("internet"[MeSH Terms] OR "internet"[All Fields] OR "internet $s$ "[All Fields] OR “internets"[All Fields])) AND ((fft[Filter]) AND (humans[Filter]) AND (english[Filter]))

\section{Dentist Drug Information Internet Filters: Full text,} Humans, English

(“"dentist s"[All Fields] OR "dentists"[MeSH Terms] OR "dentists"[All Fields] OR "dentist"[All Fields]) AND “drug"[All Fields] AND 
("inform"[All Fields] OR "informal"[All Fields] OR "informality"[All Fields] OR "informally"[All Fields] OR "informant"[All Fields] OR "informant s" $s$ All Fields] OR "informants"[All Fields] OR "information" [All Fields $]$ OR "information"[All Fields] OR "informational"[All Fields] OR “information"[All Fields] OR "informative" [All Fields] OR "informatively" [All Fields] OR "informativeness" [All Fields] OR “informativity"[All Fields] OR "informed"[All Fields] OR "informer"[All Fields] OR "informers"[All Fields] OR "informing"[All Fields] OR "informs"[All Fields]) AND ("internet"[MeSH Terms] OR "internet"[All Fields] OR "internet $s$ "[All Fields] OR "internets"[All Fields])) AND ((fft[Filter]) AND (humans[Filter]) AND (english[Filter]))

\section{Dental Drug Information Internet Filters: Full text, Humans, English}

(“"dental health services"[MeSH Terms] OR ("dental"[All Fields] AND "health"[All Fields] AND "services"[All Fields]) OR "dental health services"[All Fields] OR "dental"[All Fields] OR "dentally"[All Fields] OR "dentals"[All Fields]) AND "drug"[All Fields] AND ("inform"[All Fields] OR "informal"[All Fields] OR "informality"[All Fields] OR "informally"[All Fields] OR "informant"[All Fields] OR "informant $s$ "[All Fields] OR "informants"[All Fields] OR "information"[All Fields] OR "information"[All Fields] OR "informational"[All Fields] OR “information"[All Fields] OR "informative"[All Fields] OR "informatively"[All Fields] OR "informativeness"[All Fields] OR "informativity" [All Fields] OR "informed" [All Fields] OR "informer"[All Fields] OR "informers"[All Fields] OR "informing"[All Fields] OR "informs"[All Fields]) AND ("internet"[MeSH Terms] OR "internet"[All Fields] OR "internet s"[All Fields] OR "internets"[All Fields])) AND ((fft[Filter]) AND (humans[Filter]) AND (english[Filter]))

As a result, no studies came up with it. Another search had been done if pharmacy textbooks of drug information and some google searching engine. The authors were used drug information resources as websites or drug information resources websites for dental medication inquiries and secondary or tertiary drug information resources. The author intended some parameters to recap the drug information references suitable for dental care. Each resource summary entailed of name of resource, content, inquiries answered, type of resources, number of medications or journal covered, frequently update, last edition, price and subscription. Further, it also includes publisher, manual book, online version, website address, application type, usage of dental student recommendations, usage of the general dental practitioner, usage of specialized or consultant dentist and dentistry specialties.

\section{RESULTS}

\section{Assessment of Needs}

Corresponding to the augmented acceptance of drug use in dental treatment is the need for dentists to be warned to potential problems resulting from drug therapy. Drug information resources deliver clinicians with safer medications and play a vigorous role in improving drug safety. The drug information resources should be well equipped with all the essential resources for providing full, recent, and up-to-date information on medication queries. ${ }^{6}$ Most literature resources might be retrieved through the publisher's website or medical/pharmacy journal with the snowballing internet user. Often, access to the abstract is free of charge through an indexing searching engine. With the limited information and inherent bias delivered in an abstract, the full text should be employed to regulate the valuable article, while making a therapeutic decision. The efficient use of a drug information website is an essential skill for all healthcare providers, irrespective of their practice site, in all dentist settings. The dentist must know how to offer accurate and complete responses following their case. One of the conventional methods of new project assessment is the SWOT analysis. It means strengths, weaknesses, opportunities, and threats of the project. ${ }^{7}$ Evaluating each resource as obtainable earlier may be time-consuming, and the responses are wanted quickly for drug information inquiries. As a result, it might force only the top results clarified, leading to decisions based only on a snapshot of information. Familiar with reputable sources was available on the net and it will decrease search time and enhance practice. The weaknesses of this project are disregarding this service, no education or guidance in the usage of the drug information center, difficulties in supporting and funding for these services. The threats to this project includes no dentist is interested in this field and the plan.

\section{Scope of the Project}

The scope of the current project is to refuge dental drug information website references. The vision of the project is to select the best highquality, updated, trusted dental drug information resources, with a mission to deliver an appropriate, cost-effective website of dental drug information resources. The goals of the project is to rationalized dental medications websites references list, educate and train the dental students and practitioner about drug information resources utilization, and evaluate the clinical and economic impact of dental drug information websites. Website utilization goals to dispense health information. Therefore, the source of the content should be provided based on referenced as wanted.

Additionally, the documentation of the review process reinforces the credibility of the information provided. Provision of the date of the last update confirms that the data is current. The practitioners and patients should apply the most recent and well-established information available. The data obtained from the Web must be judgmentally evaluated before its use in making treatment decisions. Implementation of this tactic will ensure that the treatment decisions are based on high-quality information. Thus, it is refining the patient care. Moreover, applying this modality will confirm that the treatment decisions are based on high-quality information, thus improving patient care.

\section{Project Implementation}

The experts in the team should establish the dentist drug information websites. The team entails of clinical pharmacists, expert pharmacists and pharmacy technicians expert in drug information, dentists, dentists assistant, nursing and IT Member. The team should educate and train the dentist and dentist's assistant in websites of drug information-related issues. The team should set up new policies and procedures linked to the drug information services, monitor the program's implementation, and evaluate the outcome with the economic impact of the new services. As a result, the management wants to cost management plan is one of the vital things to implement a drug information center (i.e. the financial budget). The budget should reflect cost-related issues, counting education and training. Besides, the cost of equipment is wanted for the preparation and the management team meetings. The defined budget should be observed throughout the project period implementation. Besides, the dentist staff desires to attend several courses on drug information research and how to deal with it, with rationalized information on drug therapy for some diseases and basic pharmacology. Besides that, the education on drug information websites includes stability research. This education is critical for dentist staff and healthcare providers, including physicians and nurses. Another educational course for administrative officers contains the team's management and higher administration and coverage of the research agency. The projected demand to emphasis on the quality management aspect called Balance Scored Card as project performance indicators of evidence-based dentistry highlights the dental drug information with numerous elements. For instance, the customer, 


\begin{tabular}{|c|c|c|c|c|c|c|c|c|c|}
\hline & (6z) Кepot бu!punoduo & 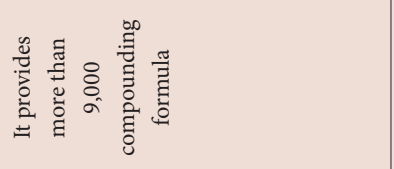 & $\begin{array}{l}\frac{3}{3} \\
\frac{0}{5} \\
3\end{array}$ & & 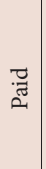 & 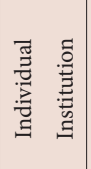 & $\approx$ & そ̊ & 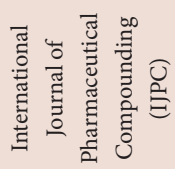 \\
\hline & (8z) 4 dy jeq이 & 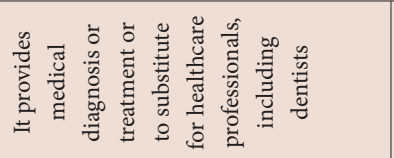 & 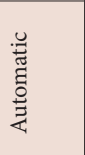 & & 㞻 & 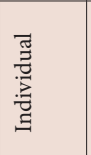 & z̊ & z̊ & 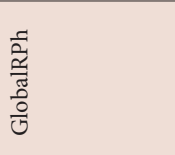 \\
\hline & (Lz) $\mathrm{sn}$ Idəu!!pəW & 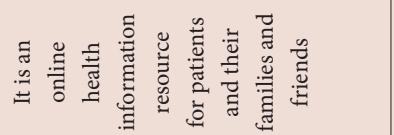 & 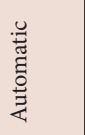 & & 节 & 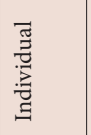 & $\stackrel{\circ}{z}$ & z̊ & 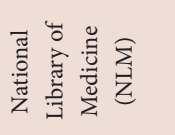 \\
\hline & (9г) pәWК|!e & 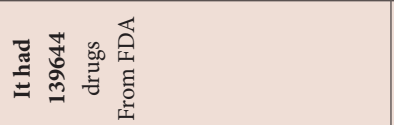 & 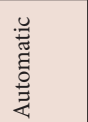 & & $\underset{\varpi}{\varpi}$ & 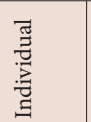 & ż & そ̊ & 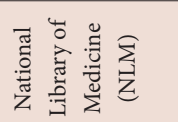 \\
\hline & (sz) Кероц әбедрәW & 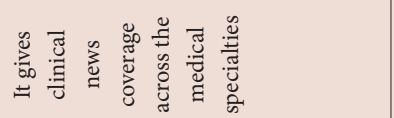 & 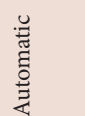 & & 壱 & 胥 & z̊ & そ̊ & 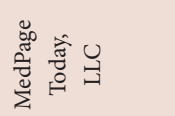 \\
\hline & (เг) $\triangle W q ә M$ & 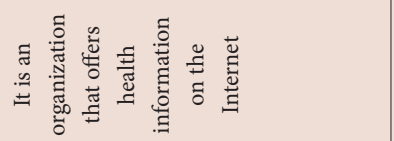 & $\begin{array}{l}\vec{\lambda} \\
\overline{\tilde{\Xi}}\end{array}$ & Ðँّ & 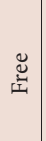 & 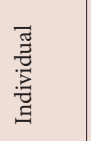 & z̊ & $\approx$ & $\sum_{\substack{0 \\
0}}^{0}$ \\
\hline & 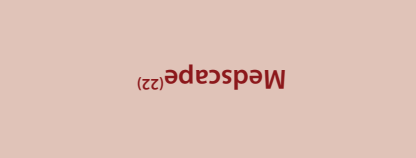 & 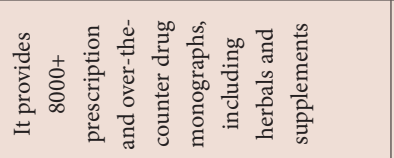 & 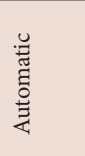 & 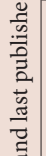 & 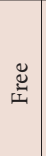 & 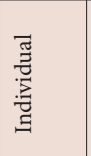 & z̊ & $\approx$ & 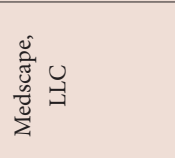 \\
\hline & 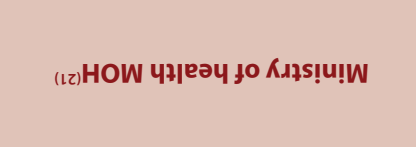 & 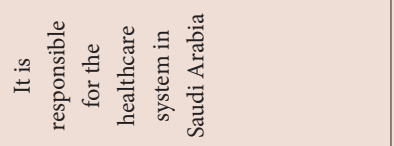 & 咅 & 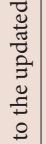 & 号 & 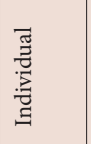 & 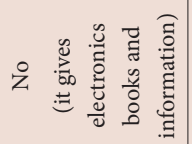 & $\cong$ & ${ }_{\substack{0 \\
0}}^{\pi}$ \\
\hline & 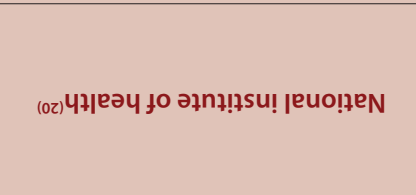 & 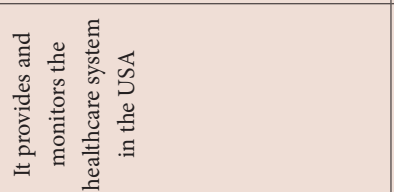 & 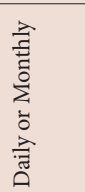 & 吾 & 离 & 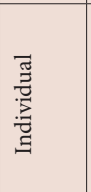 & 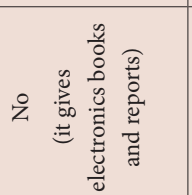 & z̊ & 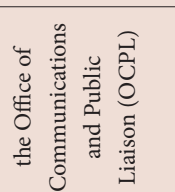 \\
\hline & ${ }_{(61)} \mathrm{OHM}$ & 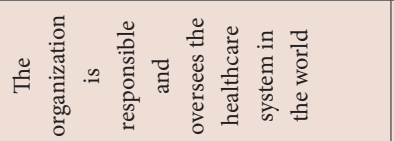 & $\begin{array}{l}\frac{3}{3} \\
\stackrel{3}{3} \\
3\end{array}$ & & 号 & 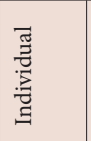 & 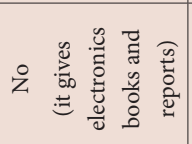 & 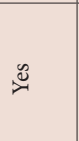 & 变 \\
\hline & (81) Кұ! & 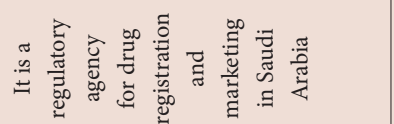 & 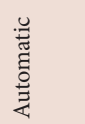 & & 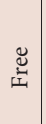 & 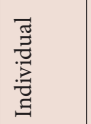 & 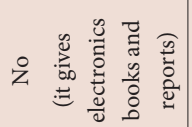 & $\cong$ & 至 \\
\hline 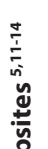 & 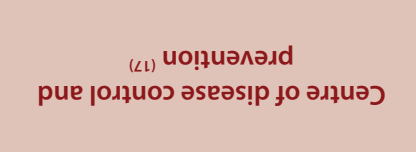 & 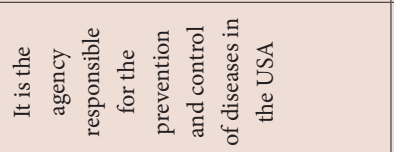 & 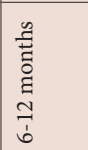 & & 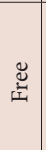 & 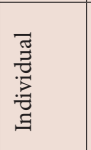 & 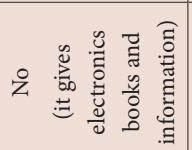 & 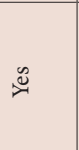 & ல \\
\hline 范 & (91) mos.s6nag & 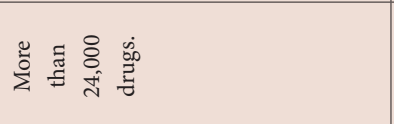 & 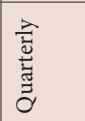 & & 芯 & 胥 & $\stackrel{\circ}{z}$ & $\triangleq$ & 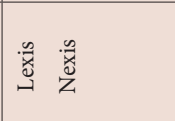 \\
\hline 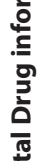 & 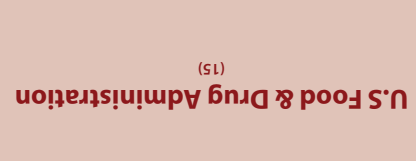 & 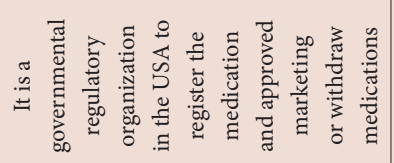 & त् & & $\underset{\varpi}{\varpi}$ & 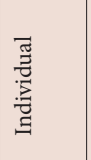 & 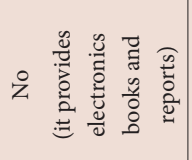 & 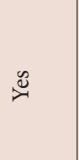 & 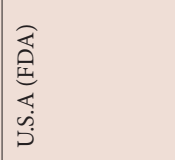 \\
\hline 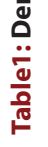 & & 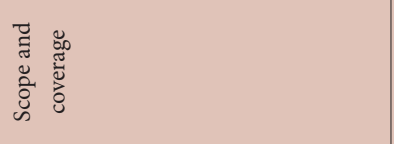 & 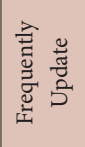 & 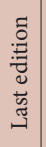 & $\underset{\Xi}{\ddot{n}}$ & 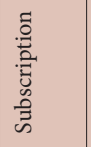 & 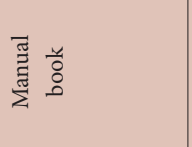 & 蔗 & 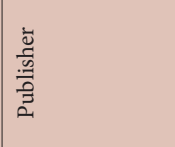 \\
\hline
\end{tabular}


finance, internal process, education, and innovation. ${ }^{8}$ There are risks in the current project: budget, scope, personnel, scheduled, technical, and quality risks. This project might be unprotected to personnel risk due to the shortage of expert dentists. It might also be exposed to budget risk due to the deficiency of budget for education and training of the dentist staff with multiple experiences. Further, this project might also be exposed to technical risks such as material was not being available. Quality risks are met due to the untrained dentist being available., ${ }^{9,10}$ Selected fourteen drug information websites for dental practice had been planned (Table 1 and 2).

\section{DISCUSSION}

There are several websites location employed as dental drug information resources. The government website was mainly established for drug registration in each country. For illustration, FDA for drug and food regulatory affairs. There are any dental medications to know about country registration or permitted indication in the USA. Another website is called SFDA drug and food registration office in Saudi Arabia. Further, another type of governmental site was the Ministery of Heath in Saudi Arabia to keep reorganized about any heathcare affair in Saudi Arabia, which dentists commonly use. ${ }^{5}$ Besides, drug therapy guidelines and healthcare statistics lead to the all medical or dental-related issues. World health organization was accountable for health around the world and it is more frequently used by dentists ${ }^{5}$ and the site of heath status and statistics around the world.

Moreover, for any dental emergency or any pandemic, or emergency of public health, the organizations will declare rationalized information regularly. Some websites are free of charge for health information, counting dental medication-related issues like WebMD, MedPage, and Medscape, which are less commonly used by dentists. ${ }^{5}$ All common medications and dental disease management are obtainable on those websites as acknowledged in Table 1 and 2.

Some websites were articulated only drug information like drug.com. It contained of the leaflet of medications registered in the USA. The drug. com checked medications names, indications, adults or pediatrics doses, precautions, and adverse drug reactions. Additional website includes patients education about dental and regular medications for dailymed and MedlinePlus. ${ }^{13,14}$ It guides the patients about the medicines and

\section{Table 2: Practice of the Dental drug information website.}

\begin{tabular}{|c|c|c|c|c|c|c|}
\hline Name of resource & Content & Inquiries answered & $\begin{array}{l}\text { Usage of dental } \\
\text { student }\end{array}$ & $\begin{array}{l}\text { Use of general } \\
\text { dental } \\
\text { practitioner }\end{array}$ & $\begin{array}{c}\text { Usage of } \\
\text { specialized } \\
\text { or consultant } \\
\text { dentist }\end{array}$ & Reference \\
\hline $\begin{array}{l}\text { U.S Food and Drug } \\
\text { administration }\end{array}$ & $\begin{array}{l}\text { a resource database for FDA } \\
\text { approved drug information, } \\
\text { evaluation of the drugs by } \\
\text { the FDA staff, and drug's } \\
\text { regulations and safety }\end{array}$ & $\begin{array}{l}\text { Its resources of the brand } \\
\text { and generic names of the } \\
\text { medicines, withdrawn drugs, } \\
\text { package insert of medications, } \\
\text { and biologic therapeutics in } \\
\text { the USA. }\end{array}$ & $\begin{array}{l}\text { Needs to be } \\
\text { available for } \\
\text { universities } \\
\text { and academic } \\
\text { institutions }\end{array}$ & Recommended & Recommended & 15 \\
\hline Drugs.com & $\begin{array}{l}\text { It is a collection of package } \\
\text { insert of medications } \\
\text { approved and marketed in } \\
\text { the USA }\end{array}$ & $\begin{array}{l}\text { It offers the dental and non- } \\
\text { dental drugs use, } \\
\text { doses protocols, interaction, } \\
\text { side effects, the possible } \\
\text { interaction between } \\
\text { medications or drugs-food, } \\
\text { their management. }\end{array}$ & $\begin{array}{l}\text { Needs to be } \\
\text { available for } \\
\text { universities } \\
\text { and academic } \\
\text { institutions }\end{array}$ & Recommended & Recommended & 16 \\
\hline $\begin{array}{l}\text { Centre of disease } \\
\text { control and } \\
\text { prevention (CDC) }\end{array}$ & $\begin{array}{l}\text { An organization dedicated to } \\
\text { protecting from any health } \\
\text { threats using scientific-based } \\
\text { information in the USA }\end{array}$ & $\begin{array}{l}\text { It sources for disease and } \\
\text { medical topics or healthy } \\
\text { lifestyles for health specialists } \\
\text { and the public, ways to control } \\
\text { the disease, centers that work } \\
\text { on it, travelers' travel advice, } \\
\text { nearby clinics, precautions, } \\
\text { and notes. } \\
\text { It organizes the guideline and } \\
\text { protocols for the management } \\
\text { of the particular condition, } \\
\text { infection control on the } \\
\text { workspaces protocols } \\
\text { safety and protection against } \\
\text { pandemic or biological } \\
\text { hazards }\end{array}$ & $\begin{array}{l}\text { Needs to be } \\
\text { available for } \\
\text { universities } \\
\text { and academic } \\
\text { institutions }\end{array}$ & Recommended & Recommended & 17 \\
\hline $\begin{array}{l}\text { Saudi Food and } \\
\text { Drug Authority }\end{array}$ & $\begin{array}{l}\text { It is an organization that } \\
\text { regulate approved medication, } \\
\text { and regulation related issues } \\
\text { in Saudi Arabia }\end{array}$ & $\begin{array}{l}\text { Its resources of dental and } \\
\text { non-dental Drug, food, } \\
\text { equipment related registration } \\
\text { information. Approved status, } \\
\text { prices in Saudi Arabia }\end{array}$ & $\begin{array}{l}\text { Needs to be } \\
\text { available for } \\
\text { universities } \\
\text { and academic } \\
\text { institutions }\end{array}$ & Recommended & Recommended & 18 \\
\hline
\end{tabular}




\begin{tabular}{|c|c|c|c|c|c|c|}
\hline Name of resource & Content & Inquiries answered & $\begin{array}{l}\text { Usage of dental } \\
\text { student }\end{array}$ & $\begin{array}{l}\text { Use of general } \\
\text { dental } \\
\text { practitioner }\end{array}$ & $\begin{array}{l}\text { Usage of } \\
\text { specialized } \\
\text { or consultant } \\
\text { dentist }\end{array}$ & Reference \\
\hline WHO & $\begin{array}{l}\text { It provides statistics of } \\
\text { healthcare conditions, disease } \\
\text { information, medication } \\
\text { information latest news } \\
\text { around the globe }\end{array}$ & $\begin{array}{l}\text { It provides Healthcare system- } \\
\text { related publications that } \\
\text { are including medications. } \\
\text { Moreover, the current health } \\
\text { crisis in countries, research, } \\
\text { and development sector } \\
\text { work to help researchers and } \\
\text { scientists to develop new } \\
\text { vaccine and solution for } \\
\text { epidemics or pandemics travel } \\
\text { precaution and notes }\end{array}$ & $\begin{array}{l}\text { Needs to be } \\
\text { available for } \\
\text { universities } \\
\text { and academic } \\
\text { institutions }\end{array}$ & Recommended & Recommended & 19 \\
\hline $\begin{array}{l}\text { National Institute of } \\
\text { Health (NIH) }\end{array}$ & $\begin{array}{l}\text { It is a national medical } \\
\text { information agency obtained } \\
\text { from researches and trails in } \\
\text { the USA }\end{array}$ & $\begin{array}{l}\text { It provides health information } \\
\text { to answer the public concerns } \\
\text { and questions, the health topic } \\
\text { and search about studies or } \\
\text { data are available related to it }\end{array}$ & $\begin{array}{l}\text { Needs to be } \\
\text { available for } \\
\text { universities } \\
\text { and academic } \\
\text { institutions }\end{array}$ & Recommended & Recommended & 20 \\
\hline $\begin{array}{l}\text { Ministry of Health } \\
(\mathrm{MOH})\end{array}$ & $\begin{array}{l}\text { It provides the public's } \\
\text { knowledge and the specialist } \\
\text { with the latest health news } \\
\text { and facts around the country }\end{array}$ & $\begin{array}{l}\text { It provides an update of } \\
\text { healthcare system information, } \\
\text { MOH formulary medications, } \\
\text { patient's rights, educational } \\
\text { content on varying health } \\
\text { topics including the sign } \\
\text { and symptoms, treatments } \\
\text { and information about the } \\
\text { condition, and health tools } \\
\text { include measuring the ideal } \\
\text { body weight. and } \\
\text { It had a calendar for world } \\
\text { health days, available services } \\
\text { and information provided by } \\
\text { the ministry to the resident } \\
\text { and Pilgrims, premarital } \\
\text { requires and precaution to be } \\
\text { taken } \\
\text { It had open database statistics } \\
\text { that offers access to the public } \\
\text { or anyone who can use the } \\
\text { data for educational, academic, } \\
\text { or knowledge purposes }\end{array}$ & $\begin{array}{l}\text { Needs to be } \\
\text { available for } \\
\text { universities } \\
\text { and academic } \\
\text { institutions }\end{array}$ & Recommended & Recommended & 21 \\
\hline Medscape & $\begin{array}{l}\text { It is a resource of medical and } \\
\text { dental specialties for medical } \\
\text { news, clinical reference, and } \\
\text { education. }\end{array}$ & $\begin{array}{l}\text { It had a drug update, medical } \\
\text { protocols, and guidelines, } \\
\text { information about the disease } \\
\text { and condition: the anatomy, } \\
\text { laboratory, and presentation } \\
\text { collections. Moreover, the tools } \\
\text { include a drug interaction } \\
\text { checker, check identification, } \\
\text { interactive diagnostics, and } \\
\text { MEDLINE database, giving } \\
\text { access to works not protected } \\
\text { by U.S. law. }\end{array}$ & $\begin{array}{l}\text { Needs to be } \\
\text { available for } \\
\text { universities } \\
\text { and academic } \\
\text { institutions }\end{array}$ & Recommended & Recommended & 22 \\
\hline
\end{tabular}

Continued.. 


\begin{tabular}{|c|c|c|c|c|c|c|}
\hline Name of resource & Content & Inquiries answered & $\begin{array}{l}\text { Usage of dental } \\
\text { student }\end{array}$ & $\begin{array}{l}\text { Use of general } \\
\text { dental } \\
\text { practitioner }\end{array}$ & $\begin{array}{l}\text { Usage of } \\
\text { specialized } \\
\text { or consultant } \\
\text { dentist }\end{array}$ & Reference \\
\hline WebMD & $\begin{array}{l}\text { It is an organization that } \\
\text { provides health information } \\
\text { with its reference to the } \\
\text { professional and public on the } \\
\text { internet }\end{array}$ & $\begin{array}{l}\text { It provides the latest news in } \\
\text { the health field, medical info } \\
\text { sources, media and graphics, } \\
\text { live events, and interactive } \\
\text { tools. Besides, it includes } \\
\text { drug's uses, side effects, } \\
\text { precautions, interactions, and } \\
\text { doses with a helpful tool that's } \\
\text { pill identification. Also, the } \\
\text { desirable price of medications }\end{array}$ & $\begin{array}{l}\text { Needs to be } \\
\text { available for } \\
\text { universities } \\
\text { and academic } \\
\text { institutions }\end{array}$ & Recommended & Recommended & 24 \\
\hline Medpage Today & $\begin{array}{l}\text { It is extensive sources that } \\
\text { cover important news for } \\
\text { health care professionals }\end{array}$ & $\begin{array}{l}\text { It had medical information } \\
\text { and news with various } \\
\text { specialties. Besides, health } \\
\text { policy and career in the } \\
\text { medical and dental care }\end{array}$ & $\begin{array}{l}\text { Needs to be } \\
\text { available for } \\
\text { universities } \\
\text { and academic } \\
\text { institutions }\end{array}$ & Recommended & Recommended & 25 \\
\hline DailyMed & $\begin{array}{l}\text { a reliable source for drug } \\
\text { information obtained from } \\
\text { FDA approved drug database }\end{array}$ & $\begin{array}{l}\text { FDA guidelines and resources } \\
\text { for drugs ( doses, indication } \\
\text { for use, adverse events, } \\
\text { precautions, warnings, } \\
\text { contraindications, ingredients, } \\
\text { product guide ), drug labeling, } \\
\text { indices and mapping files, } \\
\text { articles, and application } \\
\text { information }\end{array}$ & $\begin{array}{l}\text { Needs to be } \\
\text { available for } \\
\text { universities } \\
\text { and academic } \\
\text { institutions }\end{array}$ & Recommended & Recommended & 26 \\
\hline MedlinePlus & $\begin{array}{l}\text { A principled source of health } \\
\text { information for the public }\end{array}$ & $\begin{array}{l}\text { It provides a source of articles, } \\
\text { clinical trials, and treatment } \\
\text { options for disease and } \\
\text { conditions by age grouped or } \\
\text { systemic location, health, and } \\
\text { wellness. } \\
\text { Moreover, the drug instruction } \\
\text { on usage, why its prescribed, } \\
\text { special notes, dietary } \\
\text { education, side effects, storage } \\
\text { and overdoses management, } \\
\text { brand and generic names of } \\
\text { the drug and herbals, as well } \\
\text { video educational library }\end{array}$ & $\begin{array}{l}\text { Needs to be } \\
\text { available for } \\
\text { universities } \\
\text { and academic } \\
\text { institutions }\end{array}$ & Recommended & Recommended & 27 \\
\hline Global RPH & $\begin{array}{l}\text { It provides health data } \\
\text { in most majors, diseases } \\
\text { and management, tools } \\
\text { of calculating tools, Drug } \\
\text { pharmacokinetics, and } \\
\text { medication concentration- } \\
\text { related preparation and } \\
\text { administration. }\end{array}$ & $\begin{array}{l}\text { It had intravenous and } \\
\text { sterilization guidelines, } \\
\text { infectious disease resources, } \\
\text { laboratory values, cancer } \\
\text { agents, renal doses. Moreover, } \\
\text { IV medication dilution and } \\
\text { dosage calculations. Also, } \\
\text { health economic calculations. }\end{array}$ & $\begin{array}{l}\text { Needs to be } \\
\text { available for } \\
\text { universities } \\
\text { and academic } \\
\text { institutions }\end{array}$ & Recommended & Recommended & 28 \\
\hline $\begin{array}{l}\text { Compounding } \\
\text { today }\end{array}$ & $\begin{array}{l}\text { It provides the detailed } \\
\text { information needed to grow } \\
\text { and maintain a compounding } \\
\text { practice. Besides, it offers } \\
\text { professional compounder the } \\
\text { tools and resources required } \\
\text { in their daily activities. }\end{array}$ & $\begin{array}{l}\text { It provides information } \\
\text { on dental and non-dental } \\
\text { compounding formulas and } \\
\text { either sterile or non-sterile } \\
\text { procedure. It had stability and } \\
\text { concentration of compounding } \\
\text { medication. Besides skills } \\
\text { required of clinical and } \\
\text { distributive compounding of } \\
\text { medication }\end{array}$ & $\begin{array}{l}\text { Needs to be } \\
\text { available for } \\
\text { universities } \\
\text { and academic } \\
\text { institutions }\end{array}$ & Recommended & Recommended & 29 \\
\hline
\end{tabular}


instructions about medications uses, indication, administration, and storage procedures. The other website was a suitable website about dental compounding, or extemporaneous preparation of dental preparation, called compoundingtoday.com, and this website is paid yearly. Other websites deliberated medication preparation elated issues, pharmacokinetics calculations, and drug stability guidelines like Global Rph. ${ }^{28}$ All the earlier websites can be used by dental students and postgraduate dental specialties as free websites. Moreover, dental college can educate their students and dental faculties about those websites as drug information resources.

\section{CONCLUSION}

There are numerous dental medications information website references accessible for all dentist specialties. The majority of those references are free of deviations and more reachable than other resources. Reconnoitering the collection of dental drug websites can measure the dentist professionals to apply it in the dental field. The current project desires the dental team to apprise the website regularly and deliver education and training for dental providers. Moreover, the team can support the dental staff's logistics and financially the new project operation. Further studies is required to update the newest drug information references website and keep the dentists reorganized about the latest dental drug websites.

\section{ACKNOWLEDGEMENT}

None.

\section{CONFLICT OF INTEREST}

The authors declare that there is no conflict of interest.

\section{Funding}

None

\section{Consent for Publications}

Informed consent was obtained from all the participants

\section{Ethical Approval}

This research was exempted from research and ethical committee or an institutional review board (IRB) approval.

https://www.hhs.gov/ohrp/regulations-and-policy/decisioncharts-2018/index.html

\section{ORCID ID}

Yousef Ahmed Alomi (D) https://orcid.org/0000-0003-1381-628X

\section{ABBREVIATIONS}

MOH: Ministry of Health; KSA: Kingdom of Saudi Arabia; SWOT: Strengths, Weaknesses, Opportunities, and Threats; WHO: World Health Organization; SFDA: Saudi Food and Drug Authority; BSC: Balanced Scored Card; IT: Information Technology; NIH: National Institute of Health.

\section{REFERENCES}

1. Chauhan N, Moin S, Pandey A, Mittal A, Bajaj U. Indian aspects of drug information resources and impact of drug information centre on community. J Adv Pharm Technol Res - Medknow Publications. 2013;4(2):84-93. doi: 10.4103/2231-4040.111524, PMID 23833748. Available from: /pmc/articles/ PMC3696227.
2. Alomi YA. National Pharmacy Practice Programs at Ministry of Health in Saudi Arabia. JPharm Pharm Scien;1(2):17-8. doi: 10.24218/vjpps.2015.10.

3. Alomi YA, AL- Mudaiheem, Alsharfa A, Albassri H, Alonizi K, Alothaian M, Alreshidi M AT. National Drug Information Center Services through Ministry of Health Hotline Calling Center (937) in Saudi Arabia. Adv Pharmacoepidemiol Drug Saf. 2016;5(0):198.

4. AccessMedicine. AccessMedicine - internal medicine clinical resource [internet]; 2018. Available from: https://accessmedicine.mhmedical.com/ [cited 8/4/2021].

5. Alomi YA, Alshammari AM, Aljohani HSS. Dentist's knowledge of essential drug information resources in Saudi Arabia. PTB Reports. 2021;7(1):17-22. doi: 10.5530/PTB.2021.7.4

6. Palaian S, Mishra P, Shankar PR, Bista D, Purwar B. Contribution of the regional drug information center towards drug safety. JNMA J Nepal Med Assoc. 2006;45(161):216-8. PMID 17160101.

7. Helms MM, Nixon J. Exploring SWOT analysis - where are we now? a review of academic research from the last decade. Journal of Strategy and Mgt. 2010;3(3):215-51. doi: 10.1108/17554251011064837.

8. Enwere EN, Keating EA, Weber RJ. Balanced scorecards as a tool for developing patient-centered pharmacy services. Hosp Pharm. 2014;49(6):579-84. doi: 10.1310/hpj4906-579, PMID 24958976.

9. Ray S. The risk management process in project management - ProjectManager.com [internet]; 2017. Project Manager [cited Mar 15 2020]. Available from: https://www.projectmanager.com/blog/risk-management-process-steps.

10. Kaplan RS, Mikes A. Managing risks: A new framework [internet]; 2012. Harvard Business Review [cited Mar 15 2020]. Available from: https://hbr.org/2012/06/ managing-risks-a-new-framework.

11. Law MR, Mintzes B, Morgan SG. The sources and popularity of online drug information: an analysis of top search engine results and web page views. Ann Pharmacother. 2011;45(3):350-6. doi: 10.1345/aph.1P572, PMID 21343404

12. Malone PM, Kier KL, Stanovich JE. Drug information: A Guide for pharmacists. $3^{\text {rd }}$ ed; 2006.1-877.

13. Gabay M. The clinical practice of drug. Information. 2016.1-539.

14. Kier KL, Goldwire M. Drug information resources and literature retrieval. 2018. 619-45

15. Drugs. FDA [internet] [cited Mar 16 2021]. Available from: https://www.fda.gov/ Drugs.

16. Drugs.com. Prescription Drug Information, Interactions and Side Effects [cited Mar 16 2021]. Available from: https://www.drugs.com/.

17. Centers for Disease Control and Prevention [internet] [cited Mar 16 2021]. Available from: https://www.cdc.gov/.

18. Saudi Food and Drug Authority [Internet]. [cited 2021 Mar 16]. Available from: https://old.sfda.gov.sa/ar/Pages/default.aspx

19. WHO, World Health Organization [internet] [cited Mar 16 2021]. Available from: https://www.who.int/.

20. National Institutes of Health (NIH). Turning Discovery into Health [cited Mar 16 2021]. Available from: https://www.nih.gov/.

21. Kingdom of Saudi Arabia: Ministry of Health. Portal [internet] [cited Mar 16 2021]. Available from: https://www.moh.gov.sa/en/Pages/default.aspx.

22. Latest medical news, clinical trials, guidelines - Today on medscape [internet] [cited Mar 16 2021]. Available from: https://www.medscape.com/.

23. IBM. Watson health products [internet] [cited Mar 16 2021]. Available from: https://www.micromedexsolutions.com/home/dispatch.

24. WebMD - Better information. Better health. [Internet]. [cited 2021 Mar 16] Available from: https://www.webmd.com/

25. Today M [internet] [cited Jun 23 2021]. Available from: https://www.medpagetoday.com/.

26. DailyMed [internet] [cited Mar 16 2021]. Available from: https://dailymed.nlm nih.gov/dailymed/

27. MedlinePlus. Health information from the National Library of Medicine [internet] [cited Mar 16 2021]. Available from: https://medlineplus.gov/.

28. Clinician's ultimate reference - GlobalRPH [internet] [cited Jun 23 2021] Available from: https://globalrph.com/.

29. Compounding. Today [internet] [cited Jun 23 2021]. Available from: https://compoundingtoday.com/. 